\title{
Legal Ethics and Social Commitment Implementation in Corporate Social Responsibility (CSR) Projects of PT Indonesia Power Semarang Power Generation Unit
}

\author{
Adi Nugroho \\ \{adinugroho.semarang@gmail.com\} \\ Universitas Diponegoro, Indonesia
}

\begin{abstract}
Legal ethics and social commitment implementation in Corporate Social Responsibility (CSR) programs are important to be well managed for the benefit to the community. This implementation is also to avoid any legal issues to maintain the company's reputation. Legal ethics is basically a study of moral, intended to regulate good actions and discourage bad ones. This also a best practice guidance for the law enforcers in a community structure. In CSR projects execution, legal ethics implementation encourages ethical urgency which includes control, supervision and amendment so that it can run properly in accordance with ethical guidelines. As a result, a social order and regulation enforcement which are based on human values, openness, honesty, justice and upholding the norms would be applied in a society. Legal ethics in CSR activities would regulate the communications between individuals with the aim of justice and discourage law violation on every social component.
\end{abstract}

Keywords: Corporate CSR, Legal Ethics, Social Commitment

\section{Introduction}

The urgency of ethics implementation is vastly important in CSR project management. This issue has been going on for a long time in business world and social life. Even since Aristotle's time, ethics has become a main discussion. His thoughts are contained in his writing titled "Ethika Nicomachela". This important figure, Aristotle, argues that the social order and the appreciation of a human or a company, are not based on egoism or individual interests, but are based on altruistic things, namely paying attention to others. His view is clear that ethical urgency is all about caring for others. By adhering ethics, human life will become much more meaningful and far from anarchy desires.

Based on the understanding and urgency of ethics, a general description can be attained, that there is a meeting point between ethics and law. Both have substantial similarities and orientation towards the interests and order of human life. In this case, ethics emphasizes the discussion on the constitution about the merits of human behavior. Every human action could be valued as virtuous and wise when there are normative provisions which could be formulated against ethical messages. Likewise, a person can be judged on violation of ethics based on the agreed ethical principles.

While ethics is related to law, Scholten [1] said, both are to regulate human actions as humane, which means there are rules to be followed. On the other hand, there are rules that prohibit someone from carrying out an activity. For example, detrimental and violation of 
human rights. Scholten's opinion shows that the meeting point between ethics and law lies in the content of the substance that governs human behavior. What has been done will always receive rectifications based on determined legal and ethical provisions. There will also be obligations, orders, prohibitions and sanctions.

A legal theory that has a significant relationship with ethics is the "cybernetics legal theory". According to Winner's theory [2], the law is the central control of the communication between individuals for justice. The law was created by those whose were in power, according to the preceding premise was called the central organ. The goal implementation or control is carried out by controlling the individual behavior, avoiding disputes or applying legal sanctions of a dispute.

In this direction, every individual is expected to behave in accordance with the orders, and therefore justice can be realized. This theory shows the strategic role of policymakers who have the authority to make or give birth to the law. From the law that has successfully compiled, reformed, updated, and amended, hence the orientation could be concentrated to control communication between individuals with the aim of upholding justice. Through the implementation of the law followed by firm sanctions, it is anticipated that individual will be avoided from disputes, or individual who are involved in disputes, will find a basis for the resolution by relying on the strength of the applicable law.

Social commitment becomes an important change agent in making independence from existing performance and becoming the basis of diversity in organizational activities related to several dimensions, namely Luthans [3] suggests three-dimensional in social commitment, including:

a) Affective commitment involves the employee's emotional attachment to, identification with, and involvement in the organization. Affective commitment refers to emotional attachment, identification and involvement of an employee in an organization. A person's affective commitment will be stronger if his experience in an organization is consistent with expectations and satisfy his basic needs and vice versa. A person's goal congruence orientation towards the organization emphasizes the extent to which a person identifies himself with the organization having personal goals that are in line with organizational goals. This approach reflects a person's desire to accept and strive to realize organizational goals. There is a type of commitment related to the goal congruence approach, namely affective commitment, which shows a person's strong desire to continue working for an organization because he agrees with the organization and wants to do so. Employees who have a strong affective commitment, continue to work with the company because they want to work for that company.

b) Continuance commitment involves commitment based on the costs that the employee associates with leaving the organization. The concept of a side-batch orientation which emphasizes the contribution of a person which can sometimes be lost if that person leaves the organization. The act of leaving the organization poses a high risk because people fear losing the contribution they have made to the organization and realize that they cannot find a substitute.

c) Normative commitment involves the employee's feelings of obligation to stay within the organization. Normative commitment can be influenced by several aspects, including early socialization and the form of a person's role from the experience of the organization.

The strong link between commitment and empowerment is due to the willingness and readiness of employees in the organization to be empowered by accepting various challenges 
and responsibilities. Argyris [4] divides commitment into two, namely internal and external commitments:

a) Internal commitment is a commitment that comes from employees to complete various tasks, responsibilities and authorities based on their reasons and motivations. Empowerment is closely related to employee internal commitment. The empowerment process will be successful if there is a strong motivation and willingness to develop themselves and spur individual creativity in accepting greater responsibility.

b) External commitments are shaped by the work environment. This commitment arises because of the demands on the completion of tasks and responsibilities that must be completed by employees. The supervisor's role is very important in determining the emergence of this commitment because there is no individual awareness of the assigned task.

Empowerment is a series of processes that are carried out in stages within the organization so that it can be achieved optimally and build awareness of employees of the importance of the empowerment process so that there is a need for commitment from members to the organization, by granting authority and responsibility it will generate motivation and organizational commitment to the organization.

Empowerment that can be developed to strengthen organizational commitment [5], namely:

a) Length of work (Time)

Is the time that has been lived and in doing work on company. Getting longer someone stay in the company then it looks that he is committed to the company.

b) Trust

After the empowerment is carried out by the party's management, namely the next step build trust between management and employees. There is mutual trust among the members of the organization will be created good conditions for exchange information and advice without fear. Trust between the two can created by, among others: (1) Provide the time and resources enough for employees to complete profession; (2) Provide training ones sufficient for work needs; (3) respect different views and difference in employee success; (4) Provide access to information enough.

c) Confidence

Generating employee confidence by appreciating that ability owned by employees thus commitment towards the company getting higher. Employee confidence can be generated through, among others: (1) delegating important duties to employees; (2) seeking suggestions and ideas from employees; (3) expand tasks and build networks between department; (4) provide task instructions for job completion the good one.

d) Credibility

Maintain credibility with awards and develop a work environment encourage healthy competition so created an organization that has a performance high. This can be done in a way among others: (1) looking at employees as a strategic partner; (2) improvement targets in all parts of the work; (3) encourage individual initiative to make changes through participation; (4) help resolve differences in setting goals and priorities.

e) Accountability

Accountability of employees on authority granted with establish consistently and clearly about roles, standards and about goals assessment of employee performance. Step this is a means of evaluating performance employees in progress and responsibility responsible for the authority given. Accountability can be done in a way as follows: (1) using the path training in evaluating performance employees; (2) give clear assignments and a 
clear measure; (3) involve employees in standard setting and performance measures; (4) provide advice and assistance to employees in accomplished his task. Ethics and social commitment of the company has become the center attention in carrying out every existing task and closely related to the existence of Social Responsibility within structural stakeholders within carry out every aspect of the operation. done expected answer and meet the needs of society about infrastructure and the environment, as well has many. Legal ethics and social commitment at PT Indonesia Power Semarang has also been running according to the rules applicable law.

\section{Results and Discussions}

In this section, it will focus on the evaluation of CSR activities based on correspondence of CSR recipients of PT Indonesia Power Semarang in Gunungpati district. There are two main topics in this section, continuity of legal ethics and continuity of social commitment.

\subsection{Continuity of Legal Ethics}

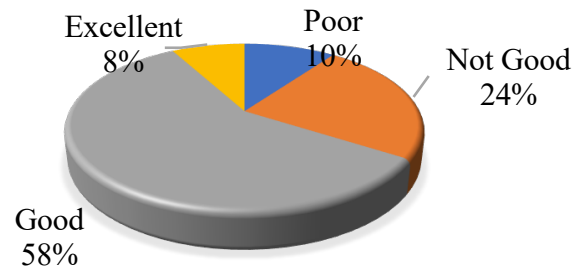

Fig. 1. Company's response in providing assistance of understanding rules and regulations on CSR projects.

The data above indicates that assistance of understanding rules and regulations on CSR projects have received a good and even excellent score $(58 \%$ and $8 \%)$. This means that majority of the community supports and accepts the legal assistance in order to improve CSR project executions and the importance of understanding. However, there are still those who think such assistance is not good (24\%), because it is considered too tied up by law.

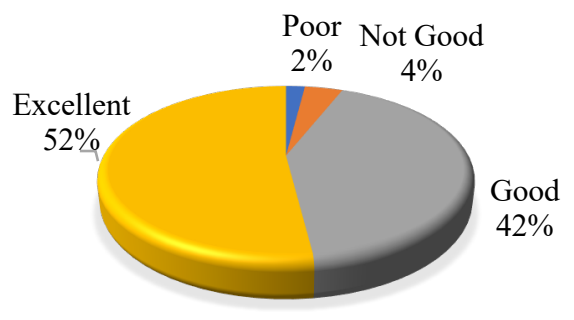

Fig. 2. Response to Assistance in the form of a Corporate Legal Ethics Book.

Research data on CSR projects also shows that many targeted communities (excellent score of $52 \%$ and good score of $42 \%$ ) provide full support for projects in the form of legal ethics books to increase public knowledge. 


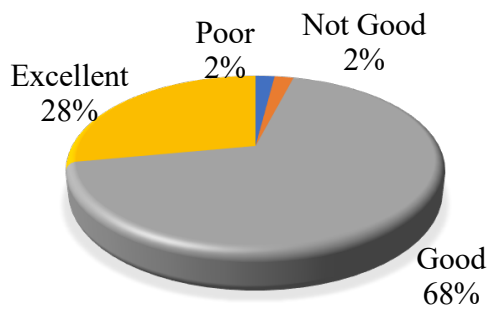

Fig. 3. Response to Assistance Training or Training on Legal Ethics Activities.

Based on the research results, the majority accepts and supports (28\% and 68\%) CSR training assistance in legal ethics for the success of every single component in the CSR project.

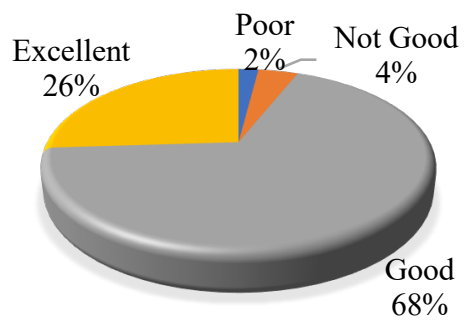

Fig. 4. Response to Joint Discussion Panel Regarding Legal Ethics.

As for the response to the help of a joint discussion panel regarding legal ethics in Gunungpati, it turns out a large amount of support from community members (26\% and 68\%). This is because it is felt that the skills in finding solutions to a problem are getting better.

\subsection{Sustaining Social Commitments}

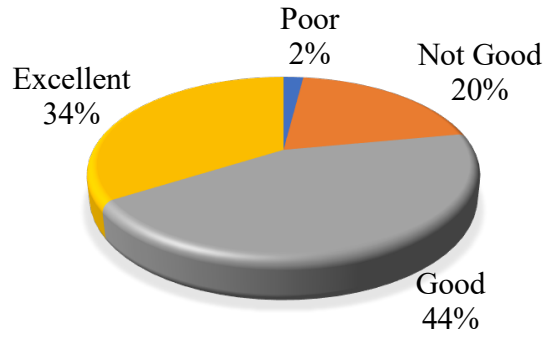

Fig. 5. Response to Providing Assistance Distribution Marketing Tools.

The description of the data above shows that a large number of people willingly to receive marketing tools to increase the economic stability of the company. 


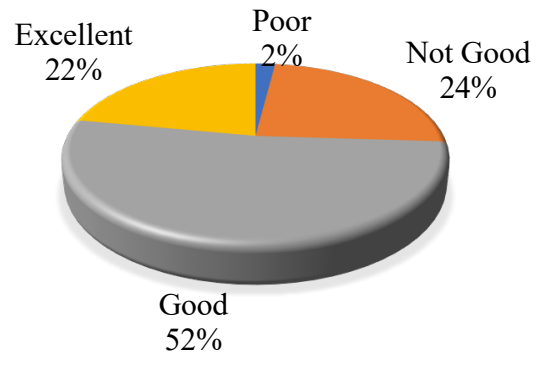

Fig. 6. Response to Cooperative Interaction Assistance with Foreign Companies.

The research results describe most community members have been supported and have received cooperation interaction assistance with foreign companies to support any distribution and cooperation in the investment division.

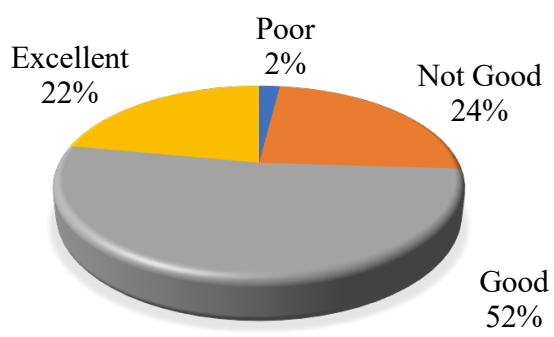

Fig. 7. Response to Help Activation of Business Communication Media.

As for CSR projects in the form of providing activation assistance for business communication media, it is widely accepted to create a directed communication flow.

\section{Conclusion}

At the end of this paper, it can be concluded that: First, the analysis results show that general public or targeted community groups of PT Indonesia Power Semarang's CSR projects in Gunungpati District of Semarang City willingly to accept and support in the form of understanding the rules for implementing CSR. However, there are also another party who think such support is not beneficial (24\%), because they do not want to be bounded by the law. Second, PT Indonesia Power Semarang CSR projects in the form of providing assistance in providing legal ethics books. This is very important in order to create a company that is sensitive to legal regulations that apply in Indonesia. Third, the provision of assistance in the form of marketing tools is very influential on the company performance and it is very important to continue in order to support the sustainability of social responsibility in the community of Mount Pati. Fourth, the form of PT Indonesia Power Semarang's CSR activities in Gunungpati District still need to balance the projects that are charitable-philanthropic with consultative-empowering in the form of assistance to communities and groups in activating business communication media in order to reach existing information. 


\subsection{Recommendations}

In the future, it is expected that CSR projects can be sustainable so that the community will develop and fully benefit from the projects. Furthermore, so that the company will have a better reputation in the eyes of the community.

\section{References}

[1] P. Scholten, "De structuur der rechtswetenschappen," 1945.

[2] M. Winner, "Group Interest in European Company Law: an Overview," Acta Univ. Sapientiae, Leg. Stud., vol. 5, no. 1, pp. 85-96, 2016.

[3] F. Luthans, M. J. Rubach, and P. Marsnik, "Going beyond total quality: The characteristics, techniques, and measures of learning organizations," Int. J. Organ. Anal., 1995.

[4] C. Argyris, "Empowerment: The emperor's new clothes," Harv. Bus. Rev., vol. 76, pp. 98-105, 1998.

[5] S. Khan, "The key to being a leader company: Empowerment," J. Qual. Particip., vol. 20, no. 1, p. 44, 1997. 